\title{
Cytokeratin expression and acetowhite change in cervical epithelium
}

\author{
P Maddox, A Szarewski, J Dyson, J Cuzick
}

\begin{abstract}
Aim-To investigate the distribution of cytokeratins 10,13,14 and 19 in biopsy specimens taken from acetowhite and non-acetowhite areas of the cervix.

Method-Cervical biopsy specimens were taken from both acetowhite and non-acetowhite areas from 44 patients who presented with abnormal cervical cytology. The specimens were snap frozen in liquid nitrogen and multiple sections taken from each specimen. Staining was performed for cytokeratins 10, 13, 14, 19 and NADPH diaphorase enzyme. The areas of each section positive for the various markers were measured.
\end{abstract}

Results-Cytokeratin 10 positive cells were greatly increased in number in acetowhite biopsy specimens compared with non-acetowhite samples $(45 \cdot 1 \% v$ 2.8\%; p < 0.0001). Cytokeratin 19 was also increased, but to a lesser extent $(17 \cdot 8 \%$ v $5.5 \% ; p<0.0001)$. In contrast, the almost universal expression of cytokeratin 13 was reduced in acetowhite biopsy specimens $(86.2 \%$ v $96.9 \%$; p $<0.0001)$. Cytokeratin 14 was found diffusely in the basal region of the stratified squamous epithelium and was marginally more apparent in the acetowhite biopsy specimens $(p=0.04)$.

Conclusion-It is suggested that the presence of cytokeratin 10 may be an essential requirement for the formation of acetowhite change in association with the cellular swelling caused by acetic acid.

(F Clin Pathol 1994;47:15-17)

Histopathology

Department

Whittington Hospital, London N19 5NF P Maddox

J Dyson

Department of

Mathematics,

Statistics and

Epidemiology,

Imperial Cancer

Research Fund, PO

Box 123, Lincoln's Inn

Fields, London WC2A 3PX

A Szarewski

J Cuzick

Correspondence to: Dr P Maddox

Accepted for publication 29 July 1993
It has already been reported ${ }^{5}$ that intracellular localised diaphorase enzyme activity can be demonstrated in viable cells, ${ }^{67}$ and that such activity subsides immediately after cell death. We used this to determine the depth to which acetic acid and iodine treatment penetrated the epithelial surface during colposcopy.

\section{Methods}

The study comprised 44 women (mean age 31 years). All the women had a borderline or mildly dyskaryotic cervical smear and were part of a study looking into the effects of stopping smoking on cervical Langerhans' cells. The study had received ethics committee approval. During colposcopy, biopsy specimens were taken both from the acetowhite area and from a non-acetowhite area and snap frozen in liquid nitrogen.

Three serial sections were cut at $8 \mu \mathrm{m}$ intervals from each specimen and placed in order on 12 slides, providing each slide with two levels taken at about $400 \mu \mathrm{m}$ intervals. An additional three sections at $150 \mu \mathrm{m}$ intervals were placed on two extra slides and stained with haematoxylin and eosin to provide a pathology report that would be representative of the histology through the biopsy specimen (see figs 4 and 5).

Staining was performed for: (1) NADPH diaphorase enzyme, using the redox indicator Nitro blue tetrazolium chloride, which is reduced by nicotinamide adenine dinucleotide diaphorase ${ }^{6} ;$ (2) cytokeratin 10 using LH2 antibody ${ }^{8}$; (3) cytokeratin 13 using monoclonal antibody $1 \mathrm{C}^{9}$; (4) cytokeratin 14 using monoclonal antibody $\mathrm{LL} 001^{10}$; (5) cytokeratin 19 using monoclonal antibody LP2K. ${ }^{8}$ All immunostained slides were treated with an avidin-biotin complex peroxidase label, demonstrated with a standard 3-3-diaminobenzidine chromagen and counterstained with $1 \%$ alcian blue. Jensen's neutral red counterstain was used for the diaphorase stained group.

A Kontron MOP videoplan image analyser was used to determine the total area and type specific cytokeratin stained area of each section. The adjacent section was used to determine the diaphorase negative region of epithelium, which was taken to be the depth to which acetic acid penetrated the epithelium. The area which was cytokeratin positive within the diaphorase negative part of the epithelium was also calculated. 
Table 1 Mean percentage positive staining cells for different cytokeratin types in matched non-acetowhitelacetowhite biopsy specimens

\begin{tabular}{|c|c|c|c|c|c|c|}
\hline \multirow[b]{2}{*}{ Cytokeratin type } & \multicolumn{2}{|l|}{ Total sample } & \multirow{2}{*}{$\begin{array}{l}z \text { score } \\
\text { ( } p \text { value) }\end{array}$} & \multicolumn{2}{|c|}{ Diaphorase negative area } & \multirow{2}{*}{$\begin{array}{l}z \text { score } \\
\text { ( } p \text { value })\end{array}$} \\
\hline & Non-acetowhite & Acetowhite & & Non-acetowhite & Acetowhite & \\
\hline $\begin{array}{l}10 \\
13 \\
14 \\
19\end{array}$ & $\begin{array}{r}2 \cdot 8 \\
96 \cdot 9 \\
8 \cdot 2 \\
5 \cdot 5\end{array}$ & $\begin{array}{l}45 \cdot 1 \\
86 \cdot 2 \\
11 \cdot 5 \\
17 \cdot 8\end{array}$ & $\begin{array}{r}5.76(<0.0001) \\
-5.16(<0.0001) \\
2.02(0.04) \\
4.28(<0.0001)\end{array}$ & $\begin{array}{r}1 \cdot 6 \\
98 \cdot 0 \\
2 \cdot 6 \\
1 \cdot 5\end{array}$ & $\begin{array}{r}47 \cdot 2 \\
89 \cdot 0 \\
5 \cdot 7 \\
11 \cdot 4\end{array}$ & $\begin{array}{r}5.78(<0.0001) \\
-4.74(<0.0001) \\
3.14(0.002) \\
4.64(<0.0001)\end{array}$ \\
\hline
\end{tabular}

^Based on Wilcoxon signed rank test for paired samples.

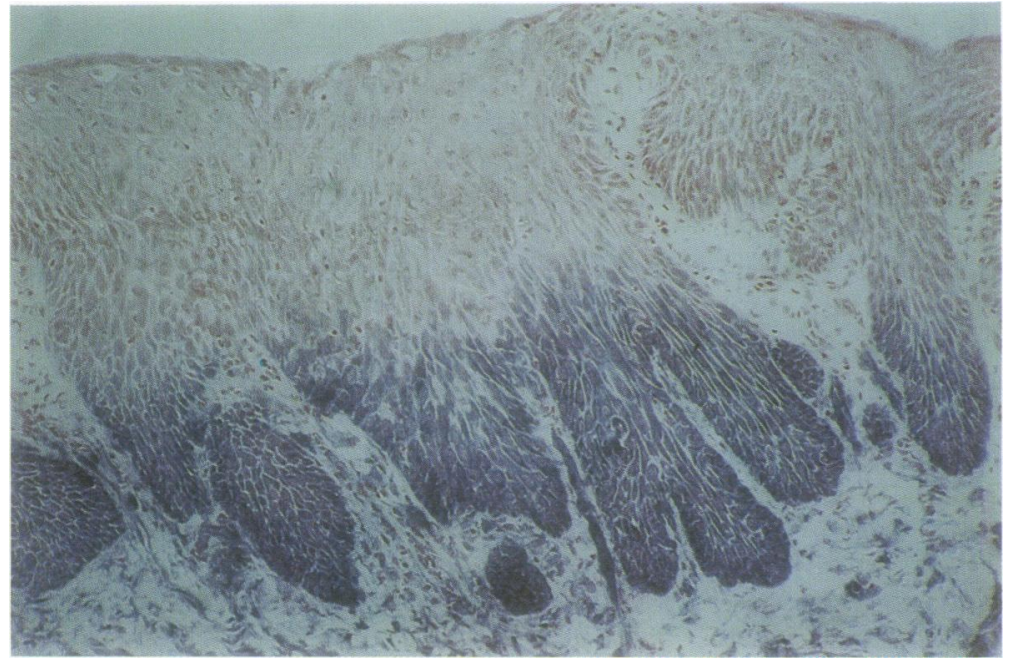

Figure 1 Frozen section stained to demonstrate diaphorase activity (blue area shows diaphorase positivity).

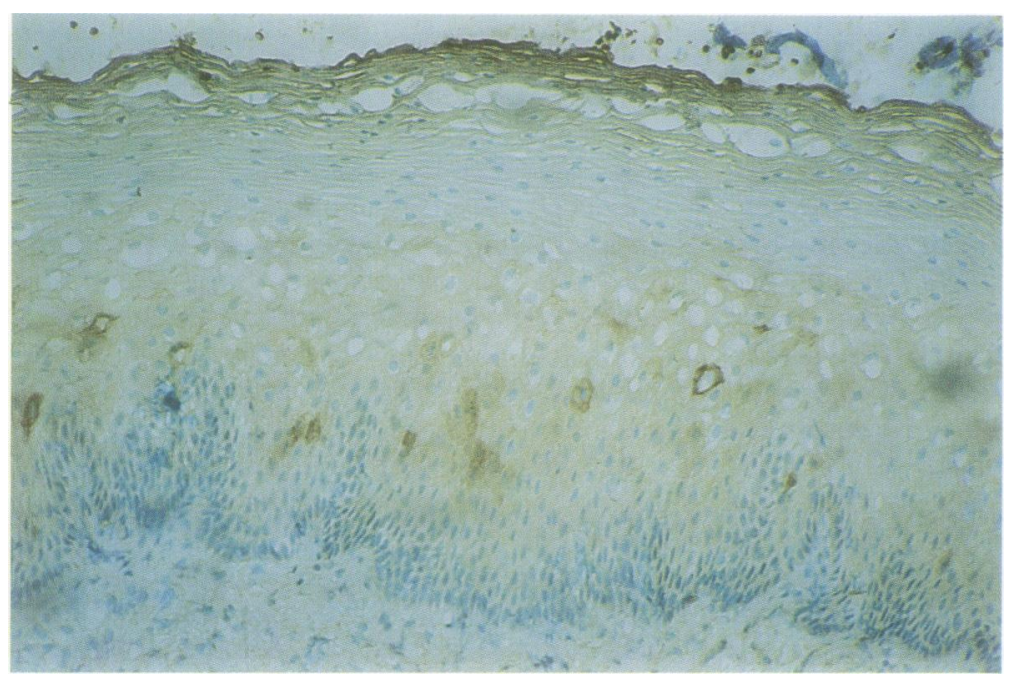

Figure 2 Frozen section immunostained to demonstrate cytokeratin 10, taken from aceto negative region of cervix.

Table 2 Histopathology reports of 44 paired biopsy specimens

\begin{tabular}{lcl}
\hline Histopathology report & $\begin{array}{c}\text { No of acetowhite } \\
\text { biopsy specimens }\end{array}$ & $\begin{array}{l}\text { No of non-acetowhite } \\
\text { biopsy specimens }\end{array}$ \\
\hline Normal squamous epithelium & 2 & 28 \\
Immature squamous metaplasia (ISM) & 3 & 9 \\
Atypical immature squamous metaplasia (AISM) & 5 & 3 \\
Congenital transformation zone (CTZ) & 3 & 0 \\
Changes suggesting human papillomavirus infection & 8 & 4 \\
(HPVI) & 8 & 0 \\
HPVI + CTZ & 3 & 0 \\
HPVI + ISM & 1 & 0 \\
HPVI + AISM & 1 & 0 \\
Cervical intraepithelial neoplasia (CIN) grade 1 & 3 & 0 \\
CIN 1 + HPVI & 9 & 0 \\
CIN 2 + HPVI & 3 & 0 \\
CIN 3 & 2 & 0 \\
CIN 3 + HPVI & 1 & 44 \\
Total cases & 44 & \\
\hline
\end{tabular}

\section{Results}

The mean percentage of cells positive for the different cytokeratins in matched non-acetowhite/acetowhite samples is shown in table 1. The greatest differences were seen for cytokeratin 10 where $2 \cdot 8 \%$ of the cells were positive in non-acetowhite areas compared with $45.1 \%$ in acetowhite biopsy specimens $(z=$ $5.76 ; p<0.0001)$. Similar results were seen when only the diaphorase negative region was considered (table 1). The appearance of cytokeratin 10 staining in the sections from acetowhite areas tended to be denser and more homogenous than the "spot" and "whorl-like" formations seen in the nonacetowhite area sections. (figs 1 and 2).

The normal expression of cytokeratin 19 in the basal cell layer of non-acetowhite biopsy specimens also became more diffuse and extended into the suprabasal region in acetowhite biopsy specimens $(5.5 \%$ v $17 \cdot 8 \%$; $\mathrm{p}<0.0001)$. In contrast, the almost universal expression of cytokeratin 13 in non-acetowhite samples was slightly but highly significantly reduced in the acetowhite specimens $(86.2 \%$ v $96.9 \% ; \mathrm{p}<0.0001)$. Cytokeratin 14 was found diffusely in the basal region of the stratified squamous epithelium and was marginally more apparent in the acetowhite biopsy specimens $(\mathrm{p}=0.04$ total sample; $\mathrm{p}=$ 0.002 in the diaphorase negative region).

The histopathology reports for all the paired biopsy specimens are shown in table 2 .

\section{Discussion}

Keratin filament proteins are regarded as the single invariable characteristic of epithelial cells, persisting even in metastatic tumours where all other identifying features are lost. To date, 19 distinct cytokeratin polypeptides have been described. ${ }^{11}$ The presence of specific keratins varies with the pattern of differentiation in stratified squamous epithelium. Keratin numbers 13, 14, and 19 have consistently been reported in normal ectocervix. Cytokeratin 10 is a suprabasal differentiation related keratin associated with areas of altered differentiation, although no morphological signs of keratinisation have so far been detected in the cervix. ${ }^{12}$

It is generally accepted that acetic acid causes cells to swell. The opaqueness of acetowhite areas may thus be due to light being reflected from turgid epithelial cells, producing the typical white appearance. This could be mediated by the type of cytokeratin present. 


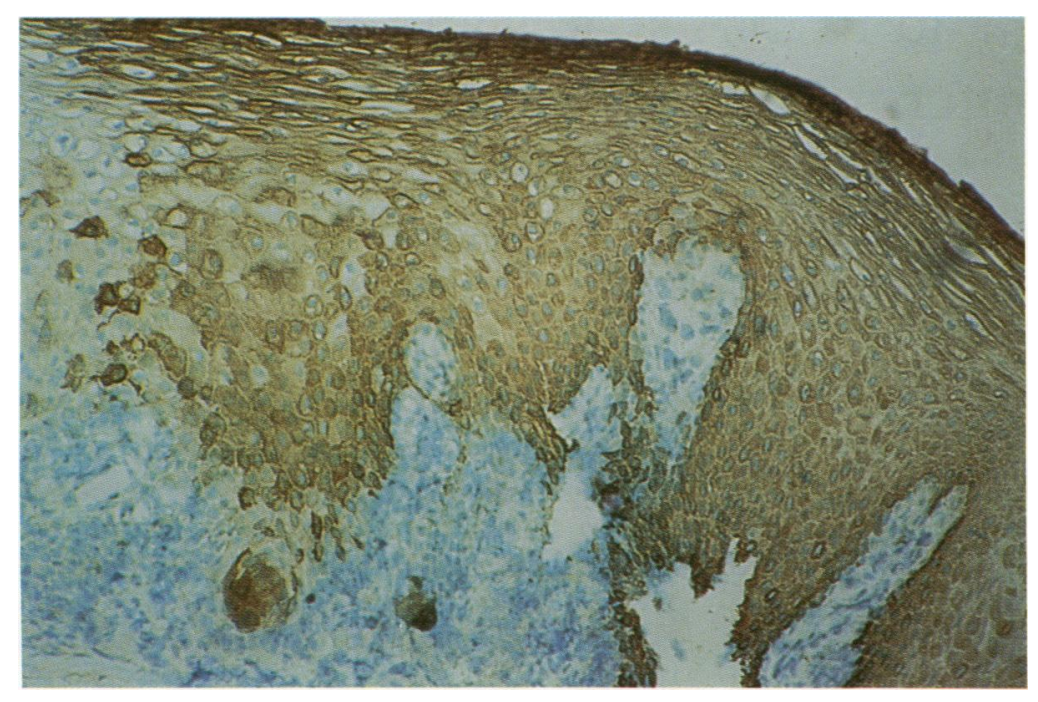

Figure 3 Frozen section immunostained to demonstrate cytokeratin 10, taken from acetowhite positive region of cervix.

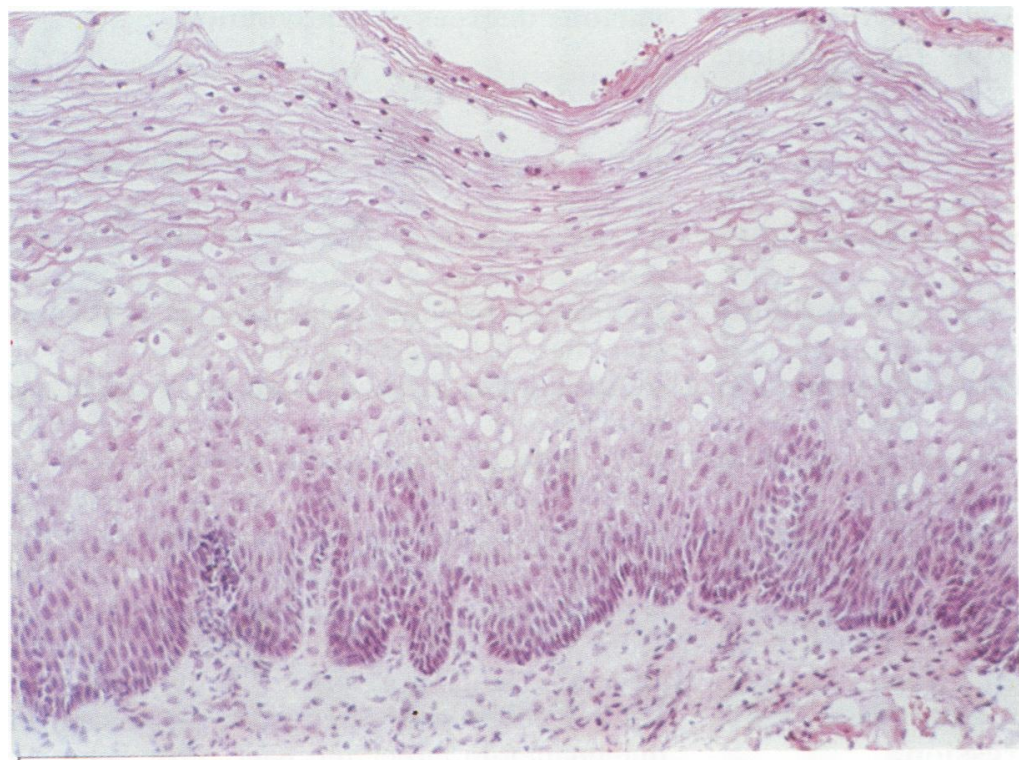

Figure 4 Frozen section of aceto negative area stained with haematoxylin and eosin.

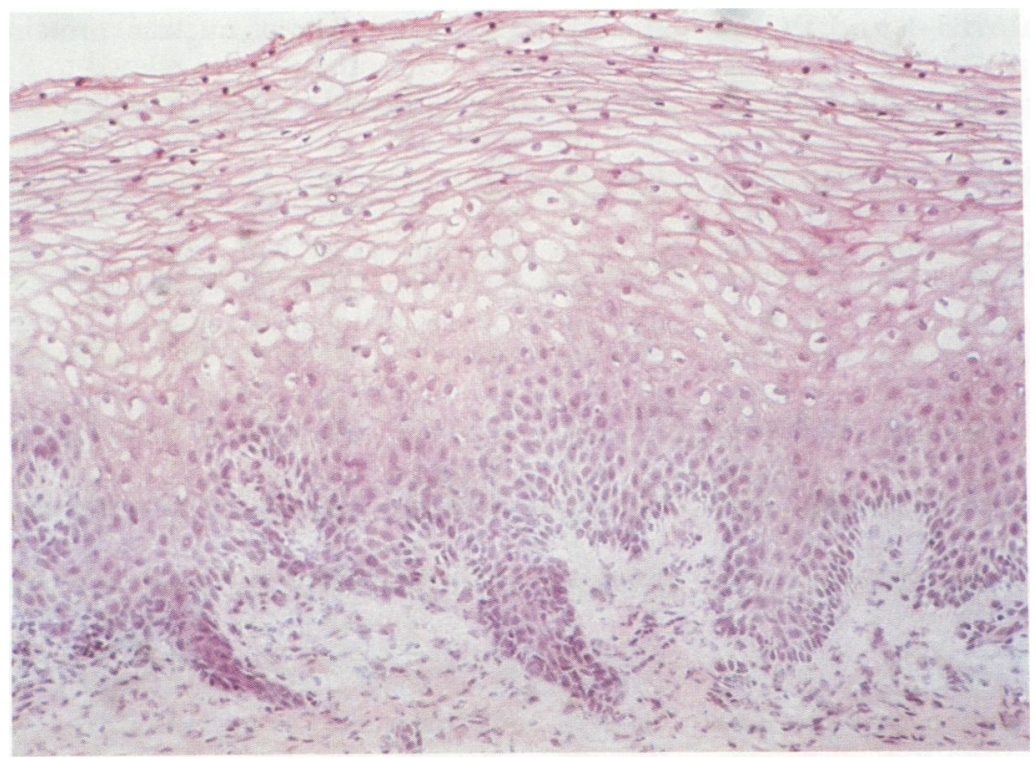

Figure 5 Frozen section of acetowhite area stained with haematoxylin and eosin.
In some cases a small percentage of cytokeratin 10 staining was found in areas of diaphorase positive epithelium which had not appeared acetowhite. These areas may represent abnormal epithelium which is below the optical level of colposcopy.

We suggest that the presence of cytokeratin 10 in cervical epithelium, in association with the cellular swelling caused by acetic acid, may be an essential requirement for the formation of acetowhite change. Further work is needed to ascertain why cytokeratin 10 is expressed under circumstances which include cervical intraepithelial neoplasia, immature squamous metaplasia, reserve cell hyperplasia and congenital transformation zones.

The histopathology reports were provided by $\mathrm{Dr} M C$ Anderson, Reader in Gynaecological Pathology, Queen's Medical Centre, Nottingham.

Hinselmann $H$. Verbesserung der Inspektionsmoglichkeiten von Vulva, Vagina und Portio. Munchen Med Wschr 1925;77:1733.

2 Hinselmann H. Die Essigsaureprobe ein bestandtell der ereiterten Kolposkopie. Deutsche Med Wschr 1938;64: $40-2$.

3 Stafl A. Cervicography: A new method for cervical cancer detection. Am F Obstet Gynecol 1981;139:815-25.

4 Anderson MC, Jordan JA, Morse AR, Sharp F. Introduction to colposcopy and documentation. In $A$ text and atlas of integrated colposcopy. London: Chapman \& Hall Medical, 1992:55-71.

5 Neumann RA, Knobler RM, Pieczkowski F, Gebhart W. Enzyme histochemical analysis of cell viability afte argon laser-induced coagulation necrosis of the skin. $f$ Am Acad Dermatol 1991;25:991-8.

6 Bancroft JO. Method 125. Oxidoreductases. II. Dihydrogenases. In: Histochemical techniques. 2nd edn. London: Butterworth \& Co. 1975:278-89.

7 Pearse AGE Principles of oxidoreductase histochemistry. In: Histochemistry, theoretical, applied. Vol 2. 3rd Ed. London: Churchill Livingstone, 1972:880-920.

8 Lane EB, Bartek J, Purkis PE, Leigh IM. Keratin antigens in differentiating skin. Ann NY Acad Sci 1985;455: 241-8.

9 Van Muijen GNP, Ruiter DJ, Franke WW, et al. Cell type heterogeneity of cytokeratin expression in complex epithelia and carcinomas as demonstrated by monoclonal antibodies specific for cytokeratins numbers 4 and 13. Exp Cell Res 1986;162:97-113.

10 Purkis PE, Steel JB, Mackenzie IC, Nathrain WBJ, Leigh IM, Lane EB. Antibody markers of basal cells in complex epithelia. $\mathcal{F}$ Cell Sci 1990;97:39-50.

11 Moll R, Franke WW, Schiller DL, Geiger B, Krepier R. The catalog of human cytokeratins: patterns of expression in normal epit

12 Smedis F, Ramaekers F, Robben $\mathrm{H}$, et al. Changing patterns of keratin expression during progression of cervical intraepithelial neoplasia. Am F Pathol 1990;136:657-67. 